Chirurgia (2017) 112: 473-476

No. $4, \quad$ July - August

Copyright@ Celsius

http://dx.doi.org/10.21614/chirurgia.112.4.473

\title{
Solitary Adrenal Metastases from Breast Invasive Ductal Carcinoma
}

\author{
Cezar Stroescu', Iulian Gilca', Dragoș Chirita', Radu Poenaru', Ana Pușcașu', Diana Pescaru', Adelina Birceanu², \\ Cornelia Nițipir ${ }^{3}$, Narcis Copcă'
}

${ }^{1}$ Center of General Surgery and Transplant, "Sf. Maria" Clinical Hospital, Bucharest, Romania

2Department of Pathology, "Sf. Maria" Clinical Hospital, Bucharest, Romania

${ }^{3}$ Department of Oncology, Elias University Emergency Hospital, Bucharest, Romania

Corresponding author:

Radu Poenaru, MD

Center of General Surgery and

Transplant, "Sf. Maria" Clinical Hospital

Bucharest, Romania

E-mail:poenarucristian23@gmail.com

\section{Rezumat \\ Metastază suprarenală unică după neoplasm mamar tip carcinom ductal invaziv}

Cele mai frecvente leziuni canceroase întâlnite la nivelul glandei suprarenale sunt metastazele de suprarenală. Dintre aceste metastaze, originea tumorală cea mai des întâlnită este cancerul pulmonar, urmată de cancerul gastric sau colonic, cel esofagian, cel hepatic sau de căi biliare şi, în ultimul rând, cancerul renal. De regulă, neoplasmul mamar de tip carcinom mamar invaziv are ca şi localizări preferate de metastazare oasele, plămânii, ganglionii, ficatul şi creierul. Metastazele de glandă suprarenală după neoplasmul mamar de tip carcinom mamar invaziv sunt extreme de rare. Vom prezenta cazul unei paciente în vârstă de 66 de ani ce a prezentat 0 metastază unică la nivelul glandei suprarenale după ce a fost diagnosticată cu carcinoma mamar invaziv triplu negativ. Pacienta a suferit o suprarenalectomie stângă totală în iunie 2016, fără a fi urmată de tratament adjuvant. La momentul redactării articolului, pacienta se află în stare clinică bună, fără semne de recidivă locală. Rolul tratamentului chirurgical şi chimioterapiei adjuvante în tratamentul metastazelor de glandă suprarenală după neoplasm mamar de tip carcinoma ductal învaziv în ceea ce priveşte rata de supraviețiure se află încă în studiu.

Cuvinte cheie: carcinoma mamar invaziv, metastază glandă suprarenală, suprarenalectomie totală 


\section{Abstract}

The usual neoplastic dissease involving suprarenal glands are adrenal metastaes. The majority of suprarenal metastatic disease arise from lung cancer, followed by the stomach and colon cancer, oesophagus, the liver/bile ducts cancer and renal cell carcinoma. Invasive mammary carcinoma usually spreads to the bones, lungs, lymph nodes, liver and the brain. Adrenal gland metastases from invasive no special type carcinoma represents an extremly low rate number of cases. We discuss about a 66 year old patient who presented with a solitary adrenal metastases from triple negative breast invasive carcinoma. The patient underwent total left adrenalectomy in June 2016. No further adjuvants therapies were performed. At the time of writing the patient is in good condition, without any evidence of recurrence. The role of surgical and adjuvant therapy in treating adrenal metastases after breast cancer in survival rate will be determined in future studies.

Key words: breast invasive ductal carcinoma, adrenal metastases, total adrenalectomy

\section{Introduction}

The usual neoplastic dissease involving suprarenal glands are adrenal metastases. Bilateral involvement is often, but may also be unilateral. When unilateral, involvement is thought to be more prevalent on the left side (1). The majority of suprarenal metastatic disease arise from lung cancer, followed by the stomach and colon cancer, oesophagus, the liver/bile ducts cancer and renal cell carcinoma (2). They are often asymptomatic and detected at regular visits from the follow-up of patients with cancer.

Mammary invasive carcinoma of no special type first spreads to the lungs, bones, liver, brain and lymph nodes. The usual organ is the bone. Relapse in breast cancer is usually fatal, therapy being mainly limited to palliation (3).

Adrenal gland metastases from invasive breast cancer are extremly rare.

\section{Case Report}

We discuss about a 66 year old patient admitted to our clinic for left upper quadrant pain. She is known with locally advanced triple negative invasive breast cancer of the right gland, for wich she was treated with preoperative chemotherapy, modified radical mastectomy and postoperative radiation therapy, two years ago. At that time no residual disease or metastases were present.
The usual blood tests were in normal range.

Abdominal ultrasound revealed a large hypoechoic left adrenal mass, wich was confirmed by CT and PET-CT scans (Figs. 1, 2).

Arterial blood presure and the plasma adrenocorticotropic hormone and cortisol levels were within a normal range.

We thinked this may be a relapse from the breast cancer and the patient underwent total left adrenalectomy in June 2016. A tumor of $9 \times 7 \times 4 \mathrm{~cm}$, encapsulated, increased consistency, white gray on section alternating with yellowish areas was found on the superior pole of the left kidney.

The pathological and immunohistochemistry reports confirmed the diagnosis of adrenal gland metastases from invasive carcinoma of no special type.

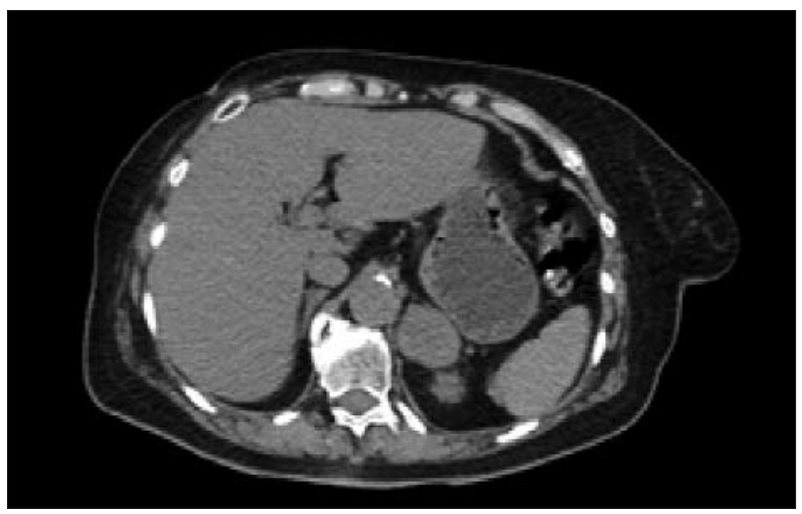

Figure 1. Left adrenal region mass on CT. 


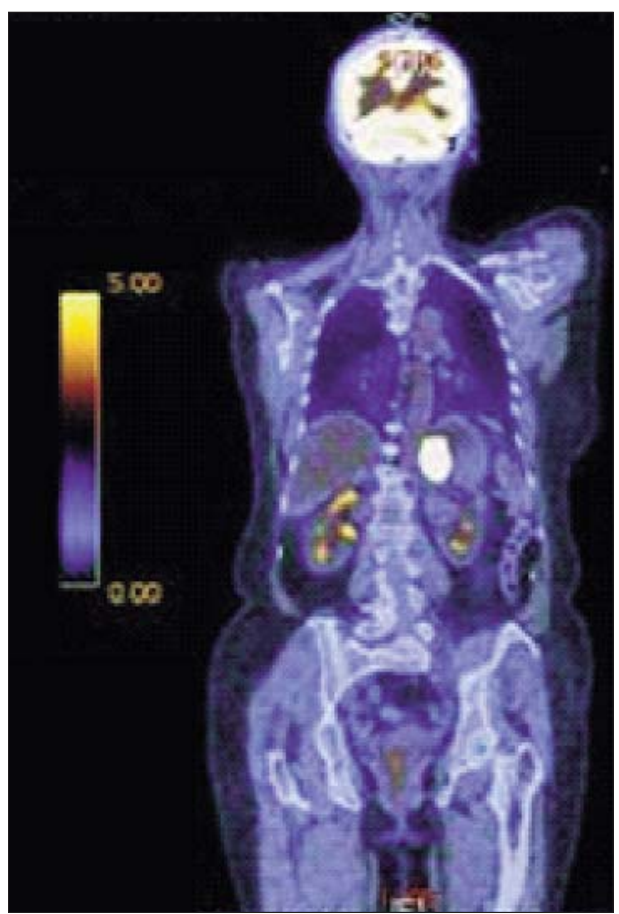

Figure 2. Left adrenal gland region mass with hypermetabolic focus on PET-CT

Postoperative evolution was favorable and the patient left the hospital on the fourth day postoperatively. No further adjuvants therapies were performed. At the time of writing the patient is in good condition, without any evidence of recurrence.

\section{Discussion}

In "Metastatic tumors of the adrenal glands: a 30-year experience in a teaching hospital", by Lam and Lo, they collected 464 cases with adrenal metastases. In their study the most common primary tumor site were the lungs $(35 \%)$, followed by the stomach (14\%), the esophagus (12\%) and the liver/bile ducts (10\%) (2).

In "Metastatic patterns of invasive lobular versus invasive ductal carcinoma of the breast", Borst and Ingold, found that in a group of 2246 cases with invasive ductal carcinoma, nobody had shown adrenal metastases. They found that adrenal metastases from mammary carcinoma is usually associated with infiltrating lobular carcinomas in $0,6 \%$ of the cases and frequently toghether with synchronous multiorgan metastases (4).

Adrenal metastases from breast invasive ductal carcinoma are extremly rare. From what we know, the first published case was in 2010 by Xiao-Jiao Liu et al. in "Solitary adrenal metastasis from invasive ductal breast cancer: an uncommon finding" (5). We managed to find only six published cases of adrenal metastases from invasive carcinoma of no special type untill the time of writing $(3,6,7,8,9)$.

Usually adrenal metastases are asymptomatic. Only few of the patients may have suprarenal gland disfunction if most of the adrenal gland is replaced or destroyed (9). Compared to metastases, primary adrenal glands malignancies such as adrenocortical carcinomas frequently secrete hormone excessively, causing certain relative symptoms (10).

Every patient presenting a history of malignancy and a mass higher than $2 \mathrm{~cm}$ in suprarenal gland should be highly considered as a possible case of adrenal gland metastases (11).

Because of the rarity of solitary adrenal metastases from mammary carcinoma, the optimal treatment of this condition is still unclear. There are no guidlines for treating this patients (5).

Metastatic breast cancer is often fatal and the treatment in most of the cases is mainly limited to palliation (3).

Studies, for other type of cancers, showed that suprarenalectomy for solitary adrenal metastases is feasible, and could lead to a longer survival in some patients $(12,13)$.

The role of surgical and adjuvant therapy in treating adrenal metastases after breast invasive carcinoma of no special type in survival rate is yet to be determined in future studies.

\section{Conclusions}

This is a rare presentation of a solitary adrenal metastases from a primary invasive ductal carcinoma of the breast. Solitary adrenal metastases can rarely occur after mammary carcinoma. Clinicians must be trained to find rare sites of metastases after initial breast cancer treat- 
ment. It is very important for patients with a history of breast cancer to undergo regular imagistic examinations. The main treatment for adrenal metastases is surgery (total adrenalectomy), followed by paraffin and immunohistochemical examinations. The role of surgical and adjuvant therapy in treating adrenal metastases after breast invasive carcinoma in survival rate will be determined in future studies.

\section{References}

1. Yuranga Weerakkody et al. Adrenal metastases. Available from: https://radiopaedia.org/articles/adrenal-metastases.

2. Lam KY, Lo CY. Metastatic tumours of the adrenal glands: a 30-year experience in a teaching hospital. Clin Endocrinol (Oxf). 2002; 56(1):95-101.

3. Akhtar K, Sherwani R, Kahkhashan E. Carcinoma breast metastasis to the suprarenal gland: an unusual presentation. Pol $\mathrm{J}$ Pathol. 2012;63(4):284-5.

4. Borst MJ, Ingold JA. Metastatic patterns of invasive lobular versus invasive ductal carcinoma of the breast. Surgery. 1993;114(4):63741; discussion 641-2.
5. Liu XJ1, Shen P, Wang XF, Sun K, Sun FF. Solitary adrenal metastasis from invasive ductal breast cancer: an uncommon finding. World J Surg Oncol. 2010;8:7. doi: 10.1186/1477-7819-8-7.

6. Yoshitomi S1, Tsuji H. A case of recurrent breast cancer with solitary adrenal gland metastasis treated with surgery and endocrine therapy. Gan To Kagaku Ryoho. 2012;39(12):2074-6. Japanese

7. Eren 00, Ordu C, Selcuk NA, Akosman C, Ozturk MA, Ozkan F, et al. Bilateral synchronous adrenal gland metastasis of invasive ductal carcinoma treated with multimodality therapy including adrenalectomy and oophorectomy. J Oncol Pharm Pract. 2016;22(1):157-60. doi: 10.1177/1078155214551314. Epub 2014 Sep 16.

8. Andjelic-Dekic N, Božovic-Spasojevic I, Miloševic S, Matijaševic M, Karadžic K. A rare case of isolated adrenal gland metastasis of invasive ductal breast carcinoma. Srp Arh Celok Lek. 2014;142(910):597-601.

9. He T, Liu J, Li Y, Jin LU, Sun S, Ni L, et al. Left adrenal gland metastasis of breast invasive ductal carcinoma: A case report. Mol Clin Oncol. 2016;4(5):859-862. Epub 2016 Mar 10.

10. Zografos GN, Perysinakis I, Kyrodimou E, Kassi E, Kaltsas G. Surgical treatment of potentially primary malignant adrenal gland tumors: An unresolved issue. Hormones (Athens). 2015;14(1):47-58.

11. Suzuki H. Laparoscopic adrenalectomy for adrenal gland carcinoma and metastases. Curr Opin Urol. 2006;16(2):47-53.

12. Kanjo $\mathrm{T}$, Albertini $\mathrm{M}$, Weber $\mathrm{S}$. Long-term disease-free survival after adrenalectomy for isolated colorectal metastases. Asian J Surg. 2006;29(4):291-3.

13. Do YR, Song HS, Kim IH: Adrenalectomy for metastatic disease to the adrenal gland from gastric cancer: report of a case. Korean $\mathrm{J}$ Intern Med. 2007;22(1):18-20. 